Revue d'histoire de l'Amérique française

REYUE D.HISTOIRE DE L'AMÉRIQUE FRANÇAISE

\title{
The Canadian Historical Review, XXXI, 2 (Toronto, June 1950): 125-144. R.A. PRESTON, "The Laconia Company of 1629: An English Attempt to Intercept the Fur Trade"
}

\section{Gordon O. Rothney}

Volume 4, numéro 2, septembre 1950

URI : https://id.erudit.org/iderudit/801647ar

DOI : https://doi.org/10.7202/801647ar

Aller au sommaire du numéro

Éditeur(s)

Institut d'histoire de l'Amérique française

ISSN

0035-2357 (imprimé)

1492-1383 (numérique)

Découvrir la revue

Citer ce compte rendu

Rothney, G. O. (1950). Compte rendu de [The Canadian Historical Review, XXXI, 2 (Toronto, June 1950): 125-144. R.A. PRESTON, "The Laconia Company of 1629: An English Attempt to Intercept the Fur Trade"]. Revue d'histoire de l'Amérique française, 4(2), 293-293. https://doi.org/10.7202/801647ar d'utilisation que vous pouvez consulter en ligne.

https://apropos.erudit.org/fr/usagers/politique-dutilisation/ 


\section{REVUE DES REVUES}

The Canadian Historical Review, XXXI, 2 (Toronto, June 1950): 125-144. R.A. Preston, "The Laconia Company of 1629: An English Attempt to Intercept the Fur Trade".

"The story of the Anglo-French struggle for North America, from the discoveries of Cabot and Cartier down to the victory of Wolfe, can be written around the theme of competition for the fur trade of the continent". This article, by Dr. Preston of the Royal Military College of Canada, deals with a plan made by some Englishmen in 1629 to strike at the sources of the furs, at a time when David Kirke's capture of Quebec had given English interests the fur monopoly for a few years. "This enterprise was known as the Laconia Company, and its basic idea was to seize territory in the interior and so to gain control of the trade even though the trading posts on the St. Lawrence should eventually be returned to France." The attempt was a failure, but it "revealed why the fur trade of New England could not compete with that of the French to the north and the Dutch to the south".

Gordon O. ROTHNEY 